\title{
SF3B1 Gene Mutation
}

National Cancer Institute

\section{Source}

National Cancer Institute. SF3B1 Gene Mutation. NCI Thesaurus. Code C133702.

A change in the nucleotide sequence of the SF3B1 gene. 